\title{
The Involvement of School Students in Criminal Activities and Its Position in the Malaysian Law
}

\author{
Assoc. Prof Dr Anita Abdul Rahim
}

Faculty of Law, Universiti Kebangsaan Malaysia aar@ukm.edu.my

\section{Dr. Tengku Noor Azira Tengku Zainudin} Faculty of Law, Universiti Kebangsaan Malaysia
tna@ukm.edu.my

\section{Dr. Ramalinggam Rajamanickam}

Faculty of Law, Universiti Kebangsaan Malaysia rama@ukm.edu.my

Doi:10.5901/mjss.2015.v6n4s3p403

\section{Abstract}

\begin{abstract}
The involvement of secondary school students in Malaysia in criminal activities is escalating and causing alarm to the society as a whole. There are several identified categories of crimes involving secondary school students, for instance theft, snatching, rape, housebreaking and robbery. In Malaysia there are specific legal provisions that govern criminal acts committed by those between the ages of 12 to 18 years old. Those provisions are the Penal Code and the Child Act 2001. From those provisions it can be seen that the age of criminal responsibility under the Malaysian criminal justice system is 10 years old while the definition of a child under the law is below 18 years of age. In consideration of the current scenario in Malaysia, this article seeks to discuss the relevant legal provisions pertaining to the status of school going children who committed crimes. In doing so, it will then be possible to identify the extent of their criminal responsibility and the types of punishment that may be imposed on this category of offenders.
\end{abstract}

Keywords: school students, crime, criminal law

\section{Introduction}

The Malaysian juvenile justice system to a large extent is based on the United Nations Convention on the Rights of the Child (UNCRC). Articles 37 and 40 of the Convention on the Rights of the Child address children who come into conflict with the law. Malaysia incorporated the main principles of the UNCRC namely non-discrimination, best interest of the child, the right to life, survival and development and participation, in its 2001 Child Act. Besides, there is one international instrument that is solely concerned with children who commit criminal offences. The United Nations Standard Minimum Rules for Administration of Juvenile Justice (the Beijing Rules) adopted by the UN in 1985 provide a detailed and comprehensive framework for the standards to be met by a national youth justice system at each stage of the process for dealing with children who commit criminal offences (Caroline Ball, Kevin McCormac \&Nogel Stone, 2001). As understood, the term juvenile or youth justice encompasses all aspects of the complex system involving the treatment of children and young people who commit offence. The Malaysian Child Act 2001 is expected to be a comprehensive mechanism in handling the issues of children who involve with criminal behaviour.

In Malaysia, there is an emerging trend of children being involved in crime and other social ills. Based on the police statistics, children involved in crime totalled 7816 cases in 2013 as compared to 3700 cases in 2012. Of this, student involvement in index crime totalled 1632 cases in 2013 as compared to 1042 cases in 2012, an increase of 57\% (http://www.thestar.com.my/Opinion/Letters/2014/04/14). Based on this source, in 2013 there was a 47\% jump in nationwide violent crime among minors aged between 12 and 17 with some even involved in murder and rape. Cases of violent crimes among school children in Malaysia went up from 368 in 2012 to 542 in 2013 . This shows that the involvement of Malaysian school students in criminal activities is escalating. 
According to the Malaysian Crime Prevention Foundation, the most common crime committed by youths, including school students is shop theft. They are also involved in violent crimes such as murder, rioting, extortion and unlawful assembly. Besides committing offences like shoplifting, extortion etc., they can also become involved in gangs. This can lead to serious and tragic consequences, such as becoming victims of rival gang clashes.

Under the Malaysian education system, there are two categories of schools, namely primary and secondary schools. Primary education begins at age 7and lasts for a period of 6 years (referred to Year 1 to Year 6). Secondary education lasts for 5 years, encompasses 3 years of lower secondary and 2 years of upper secondary (referred to Form 1 to Form 5). The following discussion shows that school students from the ages of 7 and below 10 will be exempted by the Malaysian law from any criminal liability and they will never be guilty of any criminal offence.

\section{The Provisions under the Malaysian Criminal Law}

In Malaysia there are specific legal provisions that govern criminal acts committed by children between the ages of 10 to 18. The provisions are the Penal Code and the Child Act 2001.

\subsection{The Penal Code (Act 564)}

The Malaysian criminal law provides an absolute protection for children below 10 years old who commit crimes. They are given full exemption from their criminal responsibility since they are considered doli incapax, a Latin term which literally translates as incapable of doing wrong (A.W.G Kean, 1937). The Malaysian Penal Code recognises the doctrine of doli incapax and this is clearly provided in Section 82 which reads:

"Nothing is an offence which is done by a child under ten years of age."

The law indicates that children below 10 years old are not to be blamed or made criminally liable for their act because they are innocent, immature and decent. Therefore this is an irrebuttable presumption of law and they are absolutely exempted from any criminal liability.

In relation to this, Rule 4.1 of the Beijing Rules has outlined a clear guideline on the age of criminal responsibility where it is stated that the beginning age of criminal responsibility shall not be fixed at too low an age level, bearing in mind the facts of emotional, mental and intellectual maturity. According to its commentary, the minimum age of criminal responsibility differs widely owing to history and culture. The modern approach would be to consider whether a child can live up to the moral and psychological components of criminal responsibility; that is whether a child by virtue of her or his individual discernment and understanding can be held responsible for essentially antisocial behaviour. If the age of criminal responsibility is fixed too low, or if there is no lower age limit at all, the notion of responsibility would be meaningless. In general, there is a close relationship between the notion of responsibility for delinquent or criminal behaviour and other social rights and responsibilities such as marital status, civil majority etc (Rule 4.1 of the Beijing Rules).

Malaysia considers that the age level of absolute criminal incapacity is below 10 years old and the age of criminal responsibility begins at the age of 10 . Suggestions have been made to raise the minimum age of criminal responsibility in Malaysia 12 years old. Nevertheless until now, the law still retains 10 as an age of criminal responsibility (Anita Abdul Rahim, 2012).

Another category of protection for children is 10 to 12 years old. Children between the ages of 10 to 12 are also protected by the Malaysian Penal Code but the protection is conditional and partial. They can be made criminally liable but if there is strong or clear evidence that they havenot attained sufficient maturity of understanding to judge of the nature and consequence of their act, they may rely on the defence under section 83 of the Penal Code. This is illustrated in Section 83:

"Nothing is an offence which is done by a child above ten years of age and under twelve, who has not attained sufficient maturity of understanding to judge of the nature and consequence of his conduct on that occasion."

In principle the burden of proof lies on the child to establish the insufficient maturity of understanding at the time of committing the offence. The phrase "sufficient maturity of understanding" relates closely to the capacity of knowledge of the child. The terms are very subjective and most of the time, are difficult to apply in determining the child's criminal liability (Anita Abdul Rahim, 2012). The ability of children to discern between good and evil was ascertained by some 
evidence (Thomas Crofts, 2002). Few relevant factors may be considered by the courts to interpret the terms, namely; type or nature of the crime, the child's conduct before and after the commission of the offence ( $T$ v DPP [1997]CRim.LR 127], admissions made by the child either at interview or at trial (IPH $v$ Chief Constable of South Wales [1987] Crim LR 42), evidence of upbringing and education, psychological evidence ( $V \vee$ UK, $T \vee$ UK [1997] 3 All ER 97) and also evidence of previous conviction.

In the United Kingdom, this rebuttable presumption and protection of law given to children at the ages between 10 to 14 years old has long been a subject of criticism; it is obsolete considering the changes made in the way children were dealt with by the criminal systems (Glanville Williams, 1954). The English criminal jurisdiction has abolished the age level of conditional criminal responsibility as a defence, and according to Laws $\mathrm{J}$. it was outdated and should be treated as a bad law and contrary to common sense (C (A Minor) v Director of Public Prosecutions [1996] 1AC 1). Nevertheless, the protection of children remains in the Malaysian criminal law for children in the age bracket of 10 to 12 years old.

By virtue of the above mentioned provisions, school students below the age of 10 years old are fully protected by the Malaysian criminal law. The age normally applies to Standard 1 to Standard 4 students. For students aged between 10 to 12 years old the law emphasizes on the level of immaturity and their incapacity to understand the nature and consequences of their criminal behaviour. If they are proven to be immature and incapable of judging their conduct at the time of crime commission, then they may not be criminally liable. However, if they are mature enough, the criminal liability may be imposed on them and the punishment is in accordance with the Child Act 2001.

\subsection{The Child Act 2001 (Act 611)}

The principal Act governing the handling of children in conflict with the law is the Child Act 20017, which came into force in August 2002. This Act consolidated three former Acts, the Juvenile Courts Act 1947; the Child Protection Act 1999; and the Women and Girls' Protection Act 1973. The current Child Act governs four main categories of children: 1) children in need of care and protection; 2) children in need of protection and rehabilitation; 3) children "beyond control"; and 4) children in conflict with the law. This paper focuses mainly on the fourth category, i.e. children in conflict with the law.

The Malaysian Child Act defines "child" as a person under the age of eighteen years. This definition is pursuant to the Conventions on the Rights of the Child where the UN Committee on the Rights of the Child has interpreted Article 40 of the CRC to mean that every person under the age of 18 at the time of the alleged commission of an offence must be treated under the rules of juvenile justice.

Whilst in relation to criminal proceedings, "child" is a person who has attained the age of criminal responsibility as prescribed in section 82 of the Penal Code. In terms of children who are conflict with the law, the legal definition of "child" excludes those primary students in Standard 1 to 3 (ages 7 to 9 years old). It only covers students at the ages of 10 to 17 namely those who are in Standard 4 to Form 5 under the Malaysian education system.

Generally, the Malaysian Child Act outlines the main structure, processes and procedures for responding to children who commit criminal offences. Part X of the Act stipulates special procedures for arrest, bail or remand, trial, and sentencing of children, as well as defines the roles and responsibilities of police, probation officers, the Court for Children, and various institutions handling child offenders. Pursuant to section 83(1) of the Act, a child who is arrested, detained and tried for any offence (subject to certain specified limitations) must be handled in accordance with the provisions of the Child Act, rather than the normal procedures applicable to adults. The special procedures under the Child Act modify and take precedent over any written laws relating to procedures for arrest, detention and trial. However, where the Child Act does not address a specific issue, then reference may be made to the standard procedures under the Malaysian Criminal Procedure Code.

\section{Types of Punishment for Child Offenders}

Section 91 of the Child Act 2001 provides for few types of punishments that may be imposed on the child offenders in Malaysia, including school students who commit criminal activities. The punishments include admonition and discharge the child, executing a bond of good behaviour, placing the child in the care of a relative or other fit and proper person, order of fine, compensation or costs, probating order, sending to approved school or a Henry Gurney School, whipping with not more than 10 strokes of a light cane for a male offender and imprisonment for a child aged 14 and above.

The Court For Children may order the parent or guardian of the child to execute a bond for the child's good behaviour with or without security and with one or more of the following conditions (Section 93 of Child Act 2001):-

i. that the parent or guardian accompanied by the child shall report at regular intervals to be determined by the court, at the welfare department or police station nearest to the parent's or guardian's place of residence; 
ii. that the parent or guardian accompanied by the child shall attend interactive workshops organised at designated centres established for such purpose;

iii. if the child is in an educational institution, that the parent or guardian shall consult with the child's teacher and head teacher or principal once a month for the duration of the bond;

iv. if the child is sent to an approved school or a Henry Gurney School, that the parent or guardian shall visit the child on a regular basis to be determined by the court; or

v. any other condition as the Court thinks fit.

In some cases, the Court may order the parent or guardian to pay fine, compensation or costs or both compensation and costs (Section 94 of Child Act 2001). However the parent or guardian will not be ordered to pay fine etc if they are not available or cannot be found within a reasonable time or has not conduced to the commission of the offence by neglecting to exercise due care of the child (PP v Saiful Afikin [1996] 4 MLJ 309).

Another type of punishment that is available for a child offender is probation. The probation may be ordered when the child committed any grave crime, voluntarily causing grievous hurt, rape, incest or outraging modesty or any unnatural offences provided under sections 337B, 377C (carnal intercourse against the order of nature with and without consent), 377D (outrages on decency) or 377E (inciting a child to an act of gross indecency) of the Penal Code. Before making the probation order the Court shall explain to the child in simple language suitable to his age, maturity and understanding the effect of the order and the failure to comply the order (Section 98 of Child Act 2001).

The Court For Children may also send the child offender to an approved school (Sia Yik Hung v PP [1998] 1 MLJ 450 ) if it shows that the parent or guardian of the child can no longer exercise or is incapable of exercising any proper control over him; and the child is in need of institutional rehabilitation; and it appears to the court that although the offence committed is not serious in nature, but it is expedient that the child be subject to detention for such term and under such instruction and discipline as appears most conducive to his reformation (Section 67 of Child Act 2001). According to section 2, approved school means a school established or appointed under section 65 and includes a centre. The approved school may be established or appointed by the minister for the education, training and detention of children (Section 65 of Child Act 2001).

It is to be noted that a Court for Children cannot make an order requiring a child or a school student under the age of 14 to be sent to a Henry Gurney School (Section 74 of Child Act 2001). Henry Gurney School is a school under the direction and control of the Director General of Prisons and approved by the Minister for the education, training and detention of persons to be sent there. A child can be sent to Henry Gurney School if a child is found guilty of any offence punishable with imprisonment (PP v Francis anak Kuin [2006] MLJU 109; Saiful Afikin bin Mohd Firus [1996] 4 MLJ 309). There are few situations when the child can be sent to Henry Gurney School, namely if the probation report shows that the parents or guardian of the child can no longer exercise or is incapable of exercising any proper control over him; the child is habitually in the company of persons of bad character; and the child is not suitable to be rehabilitated in an approved school. If it appears to the Court For Children that the offence committed is serious in nature and by reason of the nature of the child's criminal habits and tendencies it is expedient that the child be subject to detention for such term and under such instruction and discipline as appears most conducive to his reformation and the repression of crime, the court may send the child to Henry Gurney School.

With regard to whipping as a punishment, section 92 of the Malaysian Child Act lists the manner of executing whipping. Among others, before executing the whipping the child should be examined by a medical officer to certify that the child is in a fit state of health to undergo the whipping; the usage of a light cane with average force; and the child should wear clothes. If during the execution of the whipping the medical officer certifies that the child is not in a fit state of health to undergo the remainder of the whipping, the whipping should be finally stopped. There have been decided cases in Malaysia where the Court has imposed the sentence of whipping on the child offenders who committed rape (PP $V$ Velory Ak Libong [2005] 1 MLJU 407; PP v William Ayau [2005] 4 MLJ 328).

Though imprisonment may be imposed on children, the Act provides for some restrictions on the order. A child under the age of 14 shall not be ordered to be imprisoned for any offence or be committed to prison in default of payment of a fine, compensation or costs.(Section 96 of the Child Act). If the child can be suitably dealt with any other way whether by probation or fine or being sent to a place of detention or an approved school or a Henry Gurney School or otherwise, the court cannot order him to be imprisoned.

Pertaining to school students who commit serious crimes which are punishable with death penalty such as murder, drug trafficking etc, the law prohibits the sentence of death to be pronounced or recorded against a convicted child. (Section 97 of the Child Act).In lieu of a sentence of death, the court shall order a person convicted of an offence to be detained in a prison during the pleasure of the Yang di-Pertuan Agong if the offence was committed in the Federal Territory of Kuala Lumpur or the Federal Territory of Labuan or the Ruler or the Yang Dipertua Negeri if the offence was 
committed in the state.

The Malaysian criminal law does not allow the words "conviction" and "sentence" to be used in relation to children or school students dealt with by the Court for Children (Section 91 (2) of the Child Act 2001). In such a case, a conviction and a sentence shall be construed as a child found guilty, a finding of guilt and an order made upon a finding of guilt respectively.

\section{Concluding Remark}

As can be seen today, in Malaysia, school students as young as 12 years old, are dabbling in crimes and getting involved in drugs, gambling and other social ills. This phenomenon is undoubtedly will affect their future life. The Malaysian juvenile justice system has actually provided comprehensive legal mechanisms for handling children in conflict with the law. The mechanisms include the age of criminal responsibility, the Court for Children and trial procedures, the sentencing principles and practices, correctional schools and rehabilitation centres etc. Nevertheless, it should be realised that the new global strategies are now moving away from formal police and the court-based interventions. Evidence has clearly shown that institutionalising children has proven to be ineffective, and in fact may increase the chances that the child will go on to commit further crimes (Wivina Belmonte, UNICEF 2013). Therefore children, to a certain extent, should be taken away from the formal justice system. Apart from putting them in programmes that make them accountable for their actions and other community-based responses, another suggested alternative is to educate the school students with the basic knowledge on types of criminal behaviours and criminal law. Since the most direct link between families and communities is presently found in schools, schools have more opportunity to accomplish the mission of crime prevention among children.

As the Malaysian government has also moved forward with an integrated national Justice Reform Strategy and Plan of Action that incorporates prevention and early intervention measures, it is timely for Malaysia to introduce a criminal law subject or module in the curriculum of Malaysian schools in order to provide basic understanding of the general principles of criminal law. Besides strengthening the existing legal mechanisms to address the problem of children in conflict with the law, it is humbly submitted that the role of the Malaysian education system is also very significant to assist in handling the issue. School children, especially in the secondary schools at the ages of 13 to 17 years old, should be taught with a specific module of crimes and criminal law in the syllabus, so that they have the awareness on the seriousness of criminal conducts and the severity of the punishment that may be imposed on them if they get involved with any crimes.

\section{References}

The Penal Code (Act 574)

The Child Act 2001 (Act 611)

United Nations Convention on the Rights of the Child (UNCRC)

United Nations Standard Minimum Rules for Administration of Juvenile Justice (the Beijing Rules)

Caroline Ball, Kevin McCormac\&Nogel Stone, 2001, Young Offenders: Law, Policy and Practice, 2 ${ }^{\text {nd }}$ Ed, Sweet \& Maxwell London.

Glanville Williams, The Criminal Responsibility of Children (1954) Crim Law Review 493.

A.W.G Kean, The History of the Criminal Liability of Children (1937) Law Quarterly Review 364-370)

Anita Abdul Rahim, 2012, Jenayah Kanak-kanak dan Undang-undang Malaysia, Dewan Bahasa \& Pustaka Kuala Lumpur.

Anita Abdul Rahim, 2012, The Application of the defence of infancy under the Malaysian Criminal Law: An Overview, World Academy of Science, Engineering and Technology, Issue 67, July 2012, Amsterdam.

Wivina Belmonte, 2013, The Malaysian Juvenile Justice System: A Study of Mechanism For Handling Children in Conflict with the Law, Ministry of Women, Family \& Community Development \&UNICEF Kuala Lumpur.

Thomas Crofts, 2002, The Criminal Responsibility of Children and Young Persons, Ashgate Publishing Limited, England.

http://www.thestar.com.my/Opinion/Letters/2014/04/14

T v DPP [1997] CRim.LR 127

IPH v Chief Constable of South Wales [1987] Crim LR 42

V v UK, T v UK [1997] 3 All ER 97

C (A Minor) v Director of Public Prosecutions [1996] 1 AC 1

PP v Velory Ak Libong [2005] 1 Malayan Law Journal Unreported (MLJU) 407

PP v William Ayau [2005] 4 Malayan Law Journal (MLJ) 328

SiaYik Hung v PP [1998] 1 Malayan Law Journal (MLJ) 450

PP v Francis anak Kuin [2006] Malayan Law Journal Unreported (MLJU) 109

PP v Saiful Afikin bin Mohd Firus [1996] 4 Malayan Law Journal (MLJ) 309 